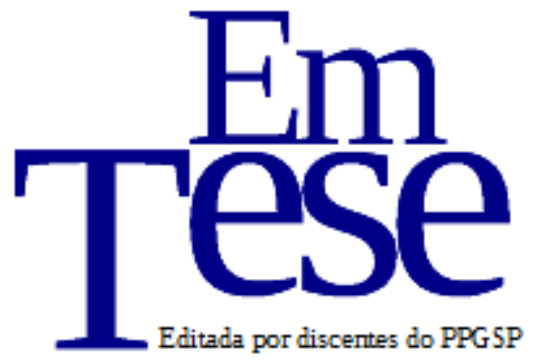

UFSC

PPG SP PROG RAMA DE

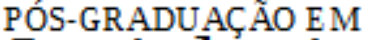

Sociologia

Política

v. 15, n. 1 (parte II), p.10-32, mar./abr., 2018.

http://dx.doi.org/10.5007/1806-5023.2018v15n1p10

\title{
Reflexões sobre o Poder Moderador nas instituições políticas brasileiras: o pretérito e o presente ${ }^{1}$
}

Eder Aparecido de Carvalho ${ }^{2}$ Carlos Henrique Gileno ${ }^{3}$

\begin{abstract}
Resumo: O artigo descreve as diferenças entre o Poder Moderador, instituído no Primeiro Reinado (1822-1831), e o suposto Poder Moderador "exercido" pelo Supremo Tribunal Federal nas instituições políticas brasileiras hodiernas. De início, podemos constatar que a modificação introduzida na aplicação da Constituição outorgada pelo primeiro imperador se desviou da teoria política acerca do Poder Neutro do intelectual e escritor franco-suiço Benjamin Constant (1767-1830). Outrossim, esse artigo analisa aspectos das interpretações que consideram o STF responsável pelo exercício do Poder Moderador na democracia nacional contemporânea: tais interpretações têm sido adotadas por parte considerável dos doutrinadores, fato que propõe a reinterpretação dos pressupostos do Poder Moderador na esfera de atuação política do STF.
\end{abstract}

Palavras-chave: Instituições Políticas Brasileiras. Poder Moderador. Primeiro Reinado. Supremo Tribunal Federal.

\section{Reflections on the Moderating Power in the brazilian political institutions: the past and the present}

\begin{abstract}
The article describes the differences between the Moderating Power established in the First Reign (1822-1831) and the supposed Moderating Power "exercised" by the Supreme Federal Court in today's Brazilian political institutions. At first we can see that the modification introduced in the application of the Constitution granted by the first emperor deviated from the political theory about the Neutral Power of the intellectual and writer Franco-Swiss Benjamin Constant (1767-1830). Moreover, this article analyzes aspects of the interpretations that consider the STF responsible for the exercise of Moderating Power in contemporary national democracy: such interpretations have been adopted by a considerable part of the doctrinators, a fact that proposes the reinterpretation of the assumptions of the Moderating Power in the sphere of political action of the STF.
\end{abstract}

Keywords: Brazilian Political Institutions. Moderating Power. First Reign. Supreme Federal Court.

\footnotetext{
1 (c) E EY Esta obra está licenciada com uma Licença Creative Commons Atribuição 4.0 Internacional.

${ }^{2}$ Assistente Social do IFSP (Campus Votuporanga) e Docente da Faculdade Futura (ICETEC). Doutorando em Ciências Sociais pela Universidade Estadual Paulista (FCL - Campus Araraquara) e Mestrado em Ciências Sociais pela Universidade Federal de São Carlos. E-mail: carvalhoeder@hotmail.com.

${ }^{3}$ Professor Assistente Doutor do Departamento de Antropologia, Política e Filosofia da Universidade Estadual Paulista (FCL - Campus Araraquara). Também é Professor do Programa de Pós-Graduação em Ciências Sociais da Universidade Estadual Paulista (FCL - Campus Araraquara). Mestrado e Doutorado em Ciências Sociais pela Universidade Estadual de Campinas. E-mail: cgileno@uol.com.br.
} 


\section{A teoria política do Poder Neutro em Benjamin Constant}

O dia 7 de setembro de 1822 representou oficialmente a separação política da vasta colônia lusitana na América do Reino Unido de Portugal e do Brasil e Algarves (1815-1822); contudo, não faltaram objeções à Independência do Brasil: distante de espelhar consenso geral que possibilitasse a transição política pacífica, a Independência foi o resultado de embates políticos entre D. Pedro I (membros do governo e seus aliados) e setores sociais oposicionistas personificados nos movimentos autonomistas contrários à mencionada separação ${ }^{4}$ (FAUSTO, 2006; OLIVEIRA, 1995).

Em 12 de outubro - trinta e cinco dias após o "grito do Ipiranga" - foi realizada sessão solene, por meio de aclamação pública ocorrida no Campo de Santana, e o título de D. Pedro I passou a ser oficialmente o de Imperador Constitucional. A Cerimônia de Sagração e Coroação aconteceu em $1^{\circ}$ de dezembro, na capela do Paço Municipal do Rio de Janeiro, tornando o Príncipe-Regente D. Pedro o primeiro representante do povo e Defensor Perpétuo do Brasil (AMBROSINI, 2004; COSTA JÚNIOR, 2002; LYNCH, 2005).

As eleições para a Assembleia Geral Legislativa e Constituinte do Império do Brasil, que já estavam previstas meses antes do grito de Independência, realizaram-se no início de 1823, com os pleitos nas Províncias acontecendo em datas distintas (FAUSTO, 2006; MACAULAY, 1993). A Assembleia foi eleita para elaborar uma Carta Magna e as sessões tiveram início em 03 de maio de 1823. Desde então, a Coroa e a Assembleia inauguraram um debate acerca do reconhecimento ou rejeição às prerrogativas de veto (direito do Imperador de negar lei que foi aprovada pela Assembleia Geral) e de dissolução (ato de fechar a Casa Legislativa), ambas reivindicadas pelo Imperador.

Nesse ínterim, a convivência entre os dois poderes se desenvolvia em torno das divergências e distante do consenso. Cabia aos governistas persuadir a maioria dos parlamentares que o projeto pautado na ordem e unidade do Império era o melhor caminho para a construção do Estado nacional moderno; convencimento esse incômodo para a Coroa, a qual nunca teve maioria consolidada na citada Assembleia (LYNCH, 2005). Ademais, existia na Assembleia brasileira o exemplo do projeto monarquiano de 1789 debatido no cerne da Revolução Francesa e que orientou os discursos de governistas e opositores no debate político brasileiro de 1823 .

Em setembro de 1789, a Assembleia Constituinte da França procurava delimitar o poder do Estado que representaria a vontade soberana do povo. Duas propostas, segundo Lynch (2005;

\footnotetext{
${ }^{4}$ Interessante recordar que foi necessário tomar algumas providências: expulsar tropas lusitanas que estavam no território brasileiro e dominar as províncias do norte e nordeste que reconheciam a autoridade portuguesa - das Cortes (TORRES, 1963). Mesmo distante do consenso geral, uma vez que houve uso da força que propiciou mortes, faz-se necessário salientar que a Independência do Brasil se consolidou em poucos anos, principalmente se comparada a outras realidades da América Latina (FAUSTO, 2006).
} 
2011), estavam na pauta ${ }^{5}$. Na primeira, defendida por Emmanuel Joseph Sieyès (1748-1836), Isaac Le Chapelier (1754-1794) e Charles-Maurice de Talleyrand-Périgord (1754-1838) - dentre outros deputados da facção democrática que se autodenominavam "patriotas" -, as prerrogativas inerentes à soberania popular deveriam ser representadas pela Assembleia Nacional (unicameral); não sendo admitido, nesse caso, poder superior ao Legislativo. Nessa proposta, a Coroa estava reduzida a um apêndice do Legislativo e o rei apareceria como simples executor das leis determinadas por aquele poder. Tratava-se, portanto, de regime de Assembleia única com pretensão de preponderância política sobre o Monarca $^{6}$, colocando a influência do poder do Imperador em segundo plano e impossibilitando a existência do exercício do Poder Moderador pela Coroa. Da mesma forma, os órgãos judiciários estariam subordinados ao Legislativo, ocasionando o "Legicentrismo".

Quanto aos defensores da segunda proposta, os políticos Pierre-Victor Malouet (17401814), Jean-Joseph Mounier (1758-1806), Trophime-Gérard - conde de Lally e barão de Tollendal (1751-1830) e Stanislas Marie Adélaïde, conde de Clermont-Tonerre (1757-1792) - contrariando argumentos inerentes à supremacia do Poder Legislativo - propugnavam um Poder Executivo forte, encarnado na Coroa, com o Monarca a incorporar a guarda dos interesses nacionais. $\mathrm{O}$ rei também seria o representante do povo e o primeiro representante da soberania nacional. Ainda, na citada proposta, defendiam-se as prerrogativas monarquianas do veto e de dissolução da câmara baixa; consequentemente, o chefe do Poder Executivo personificado no Imperador participaria do processo legislativo, fato que reforçaria a centralidade institucional e política da Coroa no interior do Estado $^{7}$. No auge desse debate, o escritor - simpatizante dos monarquianos - Jacques-Henri Bernardin de Saint-Pierre (1737-1814) empregou, porventura pela primeira vez, a expressão Poder Moderador ${ }^{8}$. Posteriormente, após derrota da facção monarquiana, Stanilas de ClermontTonnerre, por meio de sua obra Analyse raisonnée de la Constituition Française (1791), sugeriu para resolver problemas de soberania a criação de um poder diverso da trilogia clássica.

\footnotetext{
${ }^{5}$ Necessário esclarecer que também foi apresentada uma proposta ligada ao "constitucionalismo antigo, defendida pela nobreza togada e de espada”, mas também rejeitada (LYNCH, 2011, p. 04).

${ }^{6}$ Adotado na França em 1791 (Monarquia Republicana) e posteriormente na Espanha (1812) e Portugal (1822), esse modelo era uma "república em roupas de monarquia" e teria propiciado resultados desastrosos, ou seja, fracassou (LYNCH, 2005; 2011). Necessário frisar também que, no período entre 1791 e 1815, a inquietação na França era tamanha que foram elaboradas sete Constituições (ANDRADA, 2013; QUIRINO, 2005).

${ }^{7}$ Os defensores desta proposta, inspirados na Constituição da Inglaterra (monarquia constitucional e representativa), pretendiam colocar fim ao absolutismo (Antigo Regime), mas não reduzir a Coroa a mero apêndice. Entre o despotismo da Assembleia e a tirania de um só (absolutismo monárquico), havia lugar para uma monarquia constitucional. A independência da Coroa impediria a tirania feudal, de um lado, e a demagogia, de outro - defendia aqueles que passaram a ser conhecidos como "os monarquianos". Os mesmos, contavam, por vezes, com o apoio de Honoré Gabriel Riquetti, Conde de Mirabeau, o mais talentoso e popular chefe da Assembleia Nacional (LYNCH, 2005; 2011).

${ }^{8}$ Pela expressão de Saint-Pierre, não há distinção entre o Poder Moderador e o Executivo, já que ambos estariam açambarcados pelo Monarca. Caberia ao Poder Moderador manter o equilíbrio entre o Poder Executivo e a Assembleia composta por dois corpos: Câmara Alta e Câmara Baixa (LYNCH, 2005; 2011).
} 
[...] que o Rei detinha naturalmente "dois poderes perfeitamente distintos, o Poder Real e o Poder Executivo". Como chefe do Executivo o monarca só podia agir por meio de seus ministros, pois eram eles que se responsabilizavam pelos atos da Coroa inviolável. No exercício do Poder Real, todavia, o Rei era "verdadeiramente livre e irresponsável", porque precisava atuar como um "poder regulador" capaz de remediar os entrechoques dos poderes (LYNCH, 2011, p. $13)^{9}$.

A expressão seria, no entanto, consolidada e vulgarizada por Henri-Benjamin Constant de Rebecque (1767-1830), o qual introduziu a ideia da separação entre Poder Moderador e Executivo, considerando-os poderes com atribuições constitucionais distintas entre si. Tudo indica, mesmo com todas as modificações que sofreu, que a teoria do Poder Real (Moderador) construída por Benjamin Constant apoiou-se na teoria política de Stanilas de Clermont-Tonnerre $\left(\right.$ BASTOS, 2014) ${ }^{10}$.

O modelo constitucional de Benjamin Constant [(2014)1815; (2005)1814] apoiava-se em quatro poderes: Poder Moderador ${ }^{11}$, Poder Executivo ${ }^{12}$, Poder Representativo (bicameral) ${ }^{13}$ e Poder Judiciário $^{14}$. Para Benjamin Constant, o titular do Poder Moderador (Chefe de Estado) deve ser inviolável, sagrado e irresponsável politicamente perante os seus atos. Enquanto o Poder Moderador é neutro, os demais poderes (Poder Executivo, Poder Representativo e Poder Judiciário) são ativos, e por isso devem ser responsabilizados perante a nação por seus atos. Injusto seria a responsabilização se fossem passivos ante a vontade política pessoal do Monarca (BASTOS, 2014).

Ao Poder Real caberia moderar e equilibrar as ações dos demais poderes. Quando houvesse conflitos entre os mesmos, o papel do Poder Moderador seria intervencionista. Se o comportamento do Poder Executivo torna-se perigoso, o Monarca destituiria o Ministério. Se a Câmara representasse ameaça à estabilidade política nacional, o titular do Poder Moderador a dissolve instituindo novos pares ou convoca novas eleições. Por outro lado, se o Poder Judiciário perpetrar ações nocivas à sociedade, aplicando penas excessivamente rigorosas ou arbitrárias, o Monarca modera aquele conflito exercitando o seu direito de graça ao conceder o perdão. No entanto, o Monarca não pode estar acima da Constituição, pois é necessário definir os limites de

\footnotetext{
${ }^{9}$ Convém deixar claro que, na década de 1720, Voltaire apud Lynch (2011, p.3) já havia deixado registrado “numa de suas Cartas Filosóficas que, além de governante, o monarca britânico exercia um papel de árbitro entre os lordes e os comuns, evitando os conflitos civis entre plebeus e patrícios ocorridos em Roma”.

${ }^{10}$ Benjamin Constant admitiu ter encontrado o embrião do Poder Real nos escritos de Clermont-Tonnerre, principalmente na obra citada: Analyse raisonnée de la Constituition Française (2005 [1814]).

${ }^{11}$ Este poder estaria acima dos demais. Espécie de árbitro que procura o equilíbrio entre o Executivo, Legislativo e Judiciário.

${ }^{12}$ Confiado aos Ministros que cuidam da execução geral das leis.

${ }^{13}$ Ao "pé da letra" Benjamin Constant (2014 [1815]; 2005 [1814]) distingue cinco poderes ao invés de quatro. Isso porque considera o Poder Representativo como sendo dois poderes: poder representativo da continuidade (assembleia hereditária, composta de parlamentares delegados pelo Poder Real) e poder representativo da opinião (assembleia eleita por voto censitário - proprietários ou de poder econômico).

${ }^{14}$ Confiado aos tribunais que detêm o poder de julgar as particularidades da lei.
} 
legalidade: esse fator diferencia a Monarquia Constitucional da Monarquia Absolutista ou Despótica. Destarte, o Poder Real, por meio do Chefe de Estado, deve tomar precauções para não substituir ou incorporar os demais poderes (CONSTANT, 2014 [1815]; 2005 [1814]).

Quando Benjamin Constant (2014 [1815]; 2005 [1814]) traz a ideia de um Poder Ministerial ativo e verdadeiramente independente (ainda que emane do Poder Real), estabelece as responsabilidades dos ministros ${ }^{15}$ e separa, consequentemente, o Poder Executivo do Poder Moderador. Sendo os ministros responsabilizáveis e o titular do Poder Moderador inviolável e sagrado - não estando sujeito à responsabilidade alguma ${ }^{16}$ - fica evidente a separação entre a autoridade responsabilizável (Poder Executivo) e a autoridade inviolável (Poder Moderador).

Entretanto, segundo Benjamin Constant, tudo "se perde se o poder moderador vira poder executivo e se o poder executivo assume características e funções monárquicas” (BASTOS, 2014, p. 19). Assim, a natureza do Poder Moderador é diversa do poder discricionário, e o Monarca - ao integrar as atribuições do Poder Executivo - deixaria de ser neutro. Nesses termos, a arbitrariedade estaria presente a partir do instante em que se confundissem as prerrogativas constitucionais do Poder Executivo com o Poder Supremo ou Poder Real, fato que colocaria em risco a estabilidade política e a liberdade (CONSTANT, 2014 [1815]; 2005 [1814]). Diante do exposto, Benjamin Constant indicou - segundo observações de Holanda (1985) e Leal (2014) - que a distinção entre Poder Real e o Poder Executivo seria a chave de toda a organização política.

O Poder Executivo, embora possuindo prerrogativas constitucionais distintas das atribuições do Poder Moderador, constitui-se por delegação do Monarca e não do Parlamento. Dessa forma, o regime de monarquia limitado, defendido por Benjamin Constant, mesmo sob a influência inglesa, não era parlamentarista: os ministros são designados pelo Monarca e não pelo Parlamento.

O vício de quase todas as constituições (até hoje) foi não haver criado um poder neutro. Em vez disso, investiu a plenitude da autoridade a um dos poderes ativos. Quando essa soma de autoridade se reuniu no poder legislativo, a lei, que não deve descer a certas esferas, estendeu seu domínio a tudo. Existiu uma arbitrariedade e tirania sem limites. Daí os excessos do "Parlamento Longo", os das assembleias populares nas repúblicas da Itália, os da Convenção durante algumas de suas etapas. Quando essa mesma soma de autoridade se reuniu no poder executivo, houve despotismo. Daí a usurpação a que deu lugar a ditadura em Roma (CONSTANT, 2014 [1815]).

Benjamin Constant, na obra intitulada Reflexões sobre as Constituições e as Garantias (2005 [1814]), procurou resguardar os princípios monárquicos e as garantias individuais ao defender um modelo institucional e político que pudesse conciliar os antigos princípios

\footnotetext{
${ }^{15}$ Os atos do Executivo devem ser sempre atribuídos aos ministros.

${ }^{16} \mathrm{O}$ Monarca estaria acima das tempestades e as desconfianças não podem atingi-lo. O Poder Neutro está isento de qualquer intenção ou fraqueza (CONSTANT, 2014 [1815]).
} 
monárquicos aos novos direitos de cidadania ${ }^{17}$ gerados pela Revolução Francesa e consolidados na Constituição de $1791^{18}$. Se a defesa das garantias individuais aproximou Benjamin Constant do pensamento revolucionário liberal francês, a defesa dos princípios políticos monárquicos o ligou ao pensamento conservador, com o adendo de que o escritor e político franco-suiço era constitucionalista e opositor das pretensões das monarquias absolutistas de concentração do poder na Coroa (BASTOS, 2014).

Nesses termos, o Poder Moderador não governaria no sentido estrito da expressão, pois não lhe caberia qualquer iniciativa que não estivesse prevista na Constituição. Porém, o Poder Moderador não seria mero símbolo (TORRES, 1973). Quando os poderes - estruturados a partir da teoria dos três poderes de Montesquieu - entrassem em conflito, o Poder Real interviria a fim de construir a estabilidade político-institucional. Benjamin Constant (2014 [1815]; 2005 [1814]) salientou que esse modelo se adaptaria melhor ao sistema monárquico pautado nas tradições, com o Monarca detendo a faculdade exclusiva de árbitro na resolução de conflitos.

O Poder Moderador independente não se sobrepõe aos poderes Executivo, Legislativo e Judiciário. Mesmo tendo autonomia para dissolver o órgão responsável pela elaboração das leis, o Quarto Poder apenas mediaria os conflitos existentes entre as facções políticas ${ }^{19}$. Portanto, a monarquia constitucional deveria sobrepor a sua organização da estrutura institucional do Estado Moderno à monarquia absolutista, pois a base constitucional evitaria a irrupção da tirania e impossibilitaria a absorção do Poder Legislativo e do Poder Judiciário pelo Imperador. Para que uma monarquia seja compreendida como constitucional, os limites e modos que os poderes políticos estão regulados, suas atribuições e independência devem estar submetidas à legislação prevista na Constituição: a pátria não pode estar sujeita à vontade ilimitada, mas ao cumprimento literal das normas constitucionais (TORRES, 1973).

\footnotetext{
${ }^{17}$ Conveniente ressaltar que Constant (2014 [1815]; 2005 [1814]), na busca pela organização do Estado, promove proposta que combina direitos do povo (garantia de novos direitos políticos e de uma redefinição da liberdade individual) e direitos hereditários. A preocupação mais profunda, tentando fugir da abstração e procurando as garantias de que serão cumpridas, era preservar os princípios universais (direitos humanos): liberdade pessoal, liberdade religiosa, liberdade de imprensa (opinião), garantia contra o arbítrio e a posse da propriedade. Para Benjamin Constant, segundo Vieira (2014, p. 123), “era fundamental diante de governos despóticos (ou excessos do terror) preservar o que era mais caro ao indivíduo: a liberdade".

${ }^{18}$ Mesmo com excessos de terror - pois o legicentrismo permitiu que o corpo representativo se tornasse agentes da tirania - a Revolução Francesa (1789) apresenta saldos positivos, uma vez que se orienta rumo à construção de uma sociedade moderna. Benjamin Constant (2014 [1815]), inclusive, está comprometido com a instituição de uma sociedade estável com algum grau de participação política. Mesmo colocando a monarquia como forma civilizada de governo, deixa claro que os princípios de política que norteiam sua obra são aplicáveis a todas formas de governo. Reagindo à soberania popular despótica (legislaturas sem limites), tudo nos leva a crer, já salientado por Quirino (2005), que Constant não estava empenhado em conceber uma República ou Monarquia ideal. O suíço-francês apenas queria impedir que o Chefe de Estado de uma ou de outra modalidade se tornasse um déspota.

${ }^{19}$ Somente nesses momentos, o Poder Moderador estaria acima das facções. Segundo Benjamin Constant, muito bem lembrado por Quirino (2005), o Poder Moderador - também denominado de Poder Neutro, Poder Real, Poder Pacificador, etc - seria o "Poder Judiciário" dos demais poderes: Executivo, Legislativo e Judiciário.
} 


\section{A organização institucional do Poder Moderador no Primeiro Reinado}

As circunstâncias políticas da Revolução Francesa alicerçaram os primeiros argumentos de governistas e opositores na Assembleia Constituinte de 1823 referentes à institucionalização do Poder Moderador. Perante cenário político favorável às desavenças entre a Assembleia e o Monarca, fomentadas pelas discussões referentes às atribuições constitucionais do Poder Executivo e do Poder Legislativo, o conceito de Poder Moderador começou a ser empregado a partir daquela data no debate parlamentar brasileiro.

Nesse contexto, os governistas sustentaram a elaboração de um projeto político que viabilizasse a criação do Poder Moderador no desenvolvimento do processo de construção do Estado Constitucional. Embora remontasse à expressão tratada por Bernardin de Saint-Pierre e Stanilas de Clermont-Tonnerre, entre os governistas prevaleceu a doutrina liberal e constitucional de Benjamin Constant. O Poder Neutro, no cenário nacional, recairia sobre a figura do Imperador, cujas prerrogativas constitucionais eram meramente arbitrais; e, somente nos episódios de crise, interviria a fim de garantir a estabilidade política entre os poderes. Os partidários do governo imperial refletiram sobre a possibilidade de construção de um projeto que fortalecesse as atribuições constitucionais da Coroa, ao rejeitar os modelos institucionais que teriam fracassado na França (1791), na Espanha (1812) e na primeira Constituição monárquica portuguesa (1822), cujas características eram a fraqueza do Monarca diante da Assembleia, já que essa reunia atribuições maiores e mais importantes frente à Coroa: o Chefe de Estado não tinha direito do veto absoluto; e quando o tinha era frágil, refletindo a inferioridade do Monarca (LYNCH, 2005; 2011; 2014).

D. Pedro I (1798-1834) achava necessário o fortalecimento do Poder Moderador, pois a Coroa não poderia estar submetida de forma arbitrária às ações do Poder Legislativo. Para os governistas partidários do primeiro Imperador brasileiro, o Poder Moderador deveria possuir as prerrogativas constitucionais de dissolução da Câmara dos Deputados e do poder de veto absoluto às leis aprovadas pela Assembleia Parlamentar. Diante desse impasse, o Imperador - respaldado pelo apoio militar - dissolveu a Assembleia Constituinte às 00h40min do dia 12 de novembro de 1823. A passagem do dia 11 para o dia 12 de novembro ficou conhecida como a "Noite da Agonia".

As tropas, sob a ordem de D. Pedro I, cercaram a Câmara dos Deputados e interromperam os trabalhos constituintes e legislativos. Alguns parlamentares, entre eles os três irmãos Andradas - José Bonifácio (1763-1838), Martim Francisco Ribeiro (1775-1844) e Antônio Carlos Ribeiro (1773-1845) -, José Joaquim da Rocha (1777-1848), padre Belchior Pinheiro de Oliveira (17551856) e Francisco Gomes Brandão - futuro visconde de Jequitinhonha (1794-1870), sob ameaças 
de canhões e baionetas, foram presos e posteriormente exilados. Muitos brasileiros protestaram contra ato do Imperador e fecharam as portas e as janelas das suas residências durante a passagem da comitiva imperial (CASTRO, 2012).

À noite, a maioria das moradias permaneceu às escuras. A dissolução da Assembleia originou "em grande parte, uma impressão dolorosa e de sobressaltos" (LEAL, 2014, p. 79). D. Pedro I, segundo Costa (1974, p. 147), "havia, ali, perjurado a sua condição de brasileiro, de liberal e constitucional. Havia traído a si mesmo". O Imperador, já no discurso com que abrira os trabalhos da Assembleia Constituinte e Legislativa, em 03 de maio de 1823, deixou patente o desejo da institucionalização de uma Carta Magna que "fosse digna dele"20.

Nas entrelinhas do referido discurso, D. Pedro I vislumbrou a ideia de que o Poder Legislativo deveria existir desde que fosse tutelado pela Coroa. Outrossim, deixava expresso que tinha sobre o Projeto de Constituição poder de veto absoluto, uma vez que havia sido designado o Defensor Perpétuo dos interesses nacionais. Nessa condição, o Imperador estaria obrigado a suspender a Constituição, dissolver a Assembleia Nacional e convocar imediatamente novos representantes, caso os interesses expressos fossem nocivos à Nação. De fato, aquele discurso declarava que a Constituição poderia não ser aprovada se a mesma não fosse de agrado do Monarca (CASTRO, 2012; COSTA, 1974; LYNCH, 2005). Na data em que foi sagrado e coroado Imperador e Defensor Perpétuo, já tinha dito, D. Pedro I, ao povo: "Juro defender a Constituição que está para ser feita, se for digna do Brasil e de mim" (COSTA, 1974, p. 133).

Após 24 horas da dissolução da Assembleia Constituinte de 1823, o Imperador criou o Conselho de Estado. Os conselheiros ficaram incumbidos de redigir um Projeto de Constituição. A intenção do Monarca era convocar uma nova Assembleia Constituinte que debateria o anteprojeto constitucional elaborado pelo citado Conselho ${ }^{21}$. No entanto, aquele anteprojeto foi encaminhado para a apreciação das Câmaras Municipais ${ }^{22}$. Praticamente sem objeções, o Monarca acabou por dispensar a convocatória de nova Assembleia Constituinte e promoveu o juramento oficial da Lei Maior: estava outorgada a Carta Magna de 1824 (LYNCH, 2005).

\footnotetext{
${ }^{20}$ BRASIL. Assembleia Constituinte. Annaes do Parlamento Brazileiro 1823 (Pronunciamento proferido por Dom Pedro I na Assembleia Constituinte, na Sessão Imperial da Abertura (Fala do Trono), em 3 de maio de 1823). Rio de Janeiro: Typographia do Imperial Instituto Artístico, 1874.

${ }^{21} \mathrm{O}$ futuro marquês de Caravelas (José Joaquim Carneiro de Campos) foi nomeado como um dos integrantes do Conselho de Estado. Mais que isso, foi o relator encarregado de elaborar (redigir) o anteprojeto que serviria de base pela nova Assembleia Constituinte. Tido pelos principais historiadores brasileiros do período imperial (João Armitage, Januário da Cunha Barbosa, Tobias Monteiro, Otávio Tarquínio de Sousa, Hamilton Leal, José Honório Rodrigues - dentre outros) como o autor (pai) da Constituição que acabou sendo outorgada em 1824 e responsável pela introdução do Poder Moderador no sistema político brasileiro (LYNCH, 2014).

${ }^{22}$ Como não se tinha na ocasião uma Assembleia Legislativa Geral encaminhou-se o esboço de Constituição para as Câmaras Municipais do país. Foi uma forma de dizer que a Constituição, outorgada posteriormente, passou pelo "crivo" dos representantes do "povo".
} 
A dissolução da Assembleia propiciou a repentina reação pernambucana, com as cidades de Olinda e Recife pegando em armas ${ }^{23}$. Os revoltosos relataram a D. Pedro I que não elegeriam novos representantes para a Câmara Baixa, uma vez que os eleitos anteriormente não tinham perdido o mandato. Como personagens principais, no que diz respeito à crítica ao Império, destacaram-se Manuel de Carvalho Pais de Andrada (1780-1855), que assumiu - eleito pela vontade popular - a presidência da conturbada província de Pernambuco, o poeta nativista José da Natividade Saldanha (1796-1830) e o religioso e político Frei Joaquim do Amor Divino Rabelo Caneca (1779-1825).

Frei Caneca condenou o anteprojeto da Constituição enviado às Câmaras Municipais do Brasil. Entendia que a excessiva concentração de poderes nas mãos do Imperador poderia torná-lo chefe absoluto do Estado. Questionou também a temporalidade da Câmara dos Deputados e a vitaliciedade do Senado, pois não compreendia porque apenas a Câmara dos Deputados produziria motivos que justificassem a sua dissolução ${ }^{24}$. Frei Caneca também insistia que o Imperador:

[...] não é nação, não tem soberania, nem comissão da nação brasileira para arranjar esboços de Constituição e apresentá-los, não vinha o projeto de fonte legítima, e por isso se o devia rejeitar por exceção de incompetência. Muito principalmente quando vemos que estava a representação nacional usando de sua soberania em constituir a nação, e Sua Majestade, pelo mais extraordinário despotismo e de uma maneira a mais hostil, dissolveu a soberana Assembleia e se arrogou o direito de projetar Constituições (CANECA apud LEAL, 2014, p. 110).

Em 02 de julho de 1824 era proclamada, por Pais de Andrada, a Confederação do Equador, movimento separatista e republicano que envolveu principalmente Pernambuco, algumas vilas na Paraíba, Ceará e Maranhão. O conflito terminou oficialmente em 24 de setembro de 1824 com a Confederação do Equador derrotada militarmente. Todavia, alguns insurretos continuaram lutando no Ceará e Maranhão. Em 07 de novembro todos estavam derrotados (LUSTOSA, 2006; MONTEIRO, 1939). A punição aos rebeldes não encontrou apoio legal na Constituição outorgada poucos meses antes. Tribunais militares - criados e manipulados pela Coroa - de modo breve,

\footnotetext{
${ }^{23}$ A Câmara de Itu apresentou, via Diogo Antônio Feijó (1784-1843) - deputado que representou São Paulo nas Cortes de Lisboa -, algumas alterações a serem realizadas na Constituição outorgada. Dentre elas, mudança no artigo que atribuía ao Poder Moderador o direito de dissolução da Câmara dos Deputados, uma vez que deixaria o povo sem representação por, aproximadamente, dois anos, já que em menos tempo não seria possível realizar eleições e reunir os parlamentares. Na Bahia, também houve ameaça de separação que acabou sendo apaziguada pelos irmãos Miguel e Antônio Calmon, Lino Coutinho, Agostinho Gomes e Felisberto Gomes Caldeira (COSTA, 1974; LYRA, 2000; MONTEIRO, 1939).

${ }^{24}$ Indispensável lembrar que também havia diferença no que diz respeito à nomeação de senadores e deputados para cargos de Ministro de Estado ou Conselheiro de Estado. Segundo o art. 29 da Constituição de 1824, os primeiros continuavam a ter a cadeira no Senado. Quanto aos deputados, estavam sujeitos a nova eleição, ou seja, perdiam os assentos na Câmara e se submetiam a um novo pleito. Sendo reeleitos, poderiam acumular as duas funções.
} 
sumário e verbal, condenaram e executaram independente da culpa formada alguns rebeldes em Pernambuco, Ceará e Rio de Janeiro, somando dezesseis insurretos supliciados no total ${ }^{25}$.

A execução dos insurretos demonstrava o menosprezo do Monarca pela Constituição e revelava a tendência pelo exercício do poder pessoal do herdeiro de D. João VI (1767-1826). Em contrapartida, podemos dizer que a dissolução da Assembleia Constituinte de 1823 foi o início do divórcio entre a Coroa e a opinião pública. A Carta Constitucional nasceu de cima para baixo, imposta por D. Pedro I ao povo, ainda que o conceito de cidadão correspondesse a uma minoria que tinha participação política (FAUSTO, 2006).

O ponto efetivamente novo da Constituição de 25 de março de 1824, apresentada por D. Pedro I, foi a instituição do Poder Moderador $^{26}$. Considerado o Quarto Poder, o seu estabelecimento possibilitou a transição, quase que literal, da teoria política de Benjamin Constant acerca do Poder Neutro para a Lei Maior do Império (LEAL, 2014; LYNCH, 2014). Hipoteticamente, segundo o autor franco-suiço, o Poder Moderador - na experiência quadripartite de poder - perderia pujança, uma vez que o Monarca seria apenas o mediador das divergências estabelecidas entre os demais poderes constitucionais.

No entanto, D. Pedro I impôs modificações e passou a exercer o Poder Moderador e o Poder Executivo concomitantemente. $\mathrm{O}$ art. 102 da Constituição Imperial permitia interpretação segundo a qual o Monarca era o Chefe do Poder Executivo, exercendo-o através de seus Ministros. Por outro lado, o parágrafo VI do art. 101 atribuía ao titular do Poder Moderador a prerrogativa de nomear e demitir ministros sem qualquer interferência do Poder Legislativo, dissolver a Câmara dos Deputados antes do término de seu mandado, nomear senadores vitalícios e os presidentes das províncias e conceder "graças" e indultos ao revogar decisões judiciais.

Outra atribuição dada ao Imperador, expressa no Capítulo IV da Constituição, foi o direito de veto às leis aprovadas pelos parlamentares. Se o veto tinha efeito suspensivo, na execução era praticamente absoluto, uma vez que só poderia ser derrubado pela votação de três legislaturas sucessivas. O Imperador não elaborava as leis, porém, baseado nas atribuições "moderadas", poderia exercer pressão sobre a Casa Legislativa a fim de que esta se guiasse no sentido daquilo que o Monarca considerasse fundamental para os interesses da Nação. Na prática, o Poder Executivo e o Poder Real se sobrepunham os demais poderes, pois o Poder Moderador abarcava funções do Executivo e ambos estavam concentrados nas mãos de D. Pedro I (LYNCH, 2005).

\footnotetext{
${ }^{25}$ Frei Caneca, Lazaro Fontes, Agostinho Bezerra Cavalcanti, Antonio Macario, James Rodgers, Nicolau Pereira, Antonio Monte, Francisco Fragoso, Padre Mororó, José de Andrade Pessoa, Francisco Miguel Pereira Ibiapina, Luiz Ignácio de Azevedo, Feliciano Carapinima, João Guilherme Ratcliff, Joaquim da Silva Loureiro e João Metrovich.

${ }^{26}$ Segundo Carneiro de Campos apud Lynch (2014, p. 92-94): “um poder excepcional e discricionário, ainda que limitado, destinado a preservar a ordem constitucional. (...) Poder de exceção a serviço da salvaguarda do sistema constitucional". Entretanto, se muitos enxergaram como uma conquista liberal, "pouco tempo depois, ele começaria a ser considerado como a soma das possibilidades opressoras da Monarquia" (COSTA, 1974, p.150).
} 
A não observância da separação entre o Poder Executivo e o Poder Moderador talvez seja o que exemplifica mais claramente o distanciamento da Carta Magna brasileira da teoria política de Benjamin Constant. A Constituição outorgada em 1824 conjugou os dois poderes na pessoa do Imperador, que seria o delegado privativo do Poder Moderador e, embora o exercitando por meio dos seus Ministros, também era o Chefe do Poder Executivo (art. 98 e 102, respectivamente).

Enquanto Benjamin Constant identificava que a separação entre Poder Moderador e Poder Executivo era a chave de toda organização política, D. Pedro I conjecturou o Quarto Poder como a chave de toda aquela organização ${ }^{27}$ (AMBROSINI, 2004). Na prática, o Poder Moderador surgiu como elemento que debilitava a monarquia representativa, já que o rei "reina e governa" (HOLANDA, 1985), demonstrando a deturpação do pensamento do autor franco-suiço para assegurar a ambição de poder pessoal de D. Pedro I.

Consequentemente, houve reações contrárias ao modelo de Poder Moderador instalado por D. Pedro I. A Constituição de 1824 foi outorgada com a pretensão de centralizar o poder na figura de D. Pedro I, o qual - pela sua suposta formação de rei absolutista ${ }^{28}$ - faz do Poder Moderador um poder quase onipotente, utilizando-o para reforçar o poder pessoal (MERCADANTE, 1972; GILENO, 2016). A existência do Poder Moderador possibilitava ao Monarca, por exemplo, compor Ministérios da sua conveniência, independentemente da maioria parlamentar. O Monarca, ao divergir do sistema parlamentarista ${ }^{29}$, demonstrava que o único parâmetro aceitável era o seu voluntarismo exclusivista, o qual se pautava pela ausência de atos de tolerância, tornando impraticável o sistema parlamentar ${ }^{30}$ (NOGUEIRA, 2012).

De acordo com José Joaquim Carneiro de Campos, marquês de Caravelas (1768-1836), o Imperador, como Chefe de Estado, exerceria o Poder Moderador ouvindo o Conselho de Estado (art. 142). O Imperador também seria o Chefe do Poder Executivo, exercitando-o por meio dos seus Ministros e da referenda deles (arts 102 e 132).

\footnotetext{
${ }^{27}$ O liberal Zacarias de Goés e Vasconcellos (1815-1877), na obra Da natureza e limites do poder moderador (1860), promove a seguinte discussão: quais são as atribuições dos quatro poderes (Poder Moderador, Executivo, Legislativo e Judiciário)? Para o autor, a chave de toda a organização política passaria pela divisão das funções e atribuições dos poderes. A chave não seria o Poder Moderador, pois ele teria que moderar. A chave seria a divisão das funções e atribuições entre os poderes.

${ }^{28}$ Dom João VI firmara o pacto da Santa Aliança aceitando os princípios do Congresso de Viena (1815), cujo intuito era restaurar as monarquias absolutistas por toda Europa (LANZONI, 1995). Isso parece justificar a formação absolutista de Pedro I.

${ }^{29}$ D. Pedro I - dentre outros como Diogo Antônio Feijó, por exemplo - sempre se opôs ao governo de gabinete do parlamentarismo. Enquanto a oposição clamava por mais Ministros retirados da Assembleia, o Imperador (fundamentado na Constituição que não falava em parlamentarismo) nomeava e demitia de acordo com a sua conveniência. Contrariando pretensões associadas ao parlamentarismo, o Monarca procurava conservar o direito de nomear e demitir quem considerasse necessário (TORRES 1963).

${ }^{30}$ Mesmo compreendendo, confirmado pela própria Carta Magna, o "imenso poderio" do Monarca, se faz necessário não cair no extremo de considerar o poder do Imperador como absoluto (HOLANDA, 1985). Segundo Barbosa Lima citado por Ambrosini (2004) o Poder Moderador de Dom Pedro I, mesmo se afastando do Poder Neutro de Benjamin Constant, uma vez que carregava contornos absolutistas, estaria entre o despotismo e a democracia. Inclusive, para José Joaquim Carneiro de Campos, citado por Lynch (2014, p. 53), a Constituição de 1824 teria conseguido forjar "uma monarquia sem despotismo e liberdade sem anarquia".
} 
Ao fazer do imperador chefe desse poder executivo, e não simplesmente seu titular (como havia sido o caso do Poder Moderador), a intenção de Caravelas havia sido a de distinguir entre as duas esferas de ação. Como Chefe de Estado, o imperador decidiria direta e pessoalmente, auxiliado pelo Conselho de Estado, nas atribuições do Poder Moderador e naquelas do Poder Executivo, que versassem sobre política internacional - tradicional competência exclusiva dos monarcas. Como Chefe de Governo, o monarca decidiria, por meio e com a sanção do Conselho de Ministros, as demais atribuições da política interna (LYNCH, 2014, p. 98).

Essas diferenças não foram observadas por D. Pedro I na tentativa de exercer o poder pessoal, uma vez que a Constituição esteve suspensa em diversos momentos: 1) As revoltas foram reprimidas; e, posteriormente, os insurretos foram julgados e executados por tribunais militares sem que houvesse procedimento judicial explícito na Carta Magna; 2) Apenas trinta meses depois da dissolução da Assembleia Geral Constituinte é que se deu início aos trabalhos na Assembleia Geral Legislativa. Neste período, foi estimulado um governo centrado no exercício do poder pessoal do Imperador Constitucional, uma vez que o poder de legislar delegado à Assembleia inexistiu.

Diante dos atos que objetivavam a consolidação do poder pessoal de D. Pedro I, é necessário avaliar se o Poder Moderador obstaculizou a representação política personificada na liberdade de decisão dos deputados, pois existia a recorrente ameaça de dissolução da Câmara. Entretanto, após a dissolução da Assembleia Constituinte de 1823, e a partir da primeira legislatura instaurada em $1826^{31}$, D. Pedro I acabou por não mais fazer uso daquela prerrogativa de dissolução. Mesmo diante das disputas entre a Coroa e a Câmara dos Deputados, que não parava de crescer, o primeiro Imperador absteve-se da ação de dissolver as legislaturas.

Relevante deixar registrado, no entanto, que no Primeiro Reinado, segundo trabalho organizado pela Câmara dos Deputados (1889), existiram 10 Ministérios, todos de curta duração, pois na média não conseguiram romper o primeiro ano de exercício. Os dois Gabinetes que mais resistiram foram dissolvidos assim que romperam os 24 meses de existência. Assim, se D. Pedro I deixou de dissolver a Câmara dos Deputados a partir da primeira legislatura instaurada em 1826, os Ministérios não tiveram a mesma sorte ${ }^{32}$.

A Carta Magna deixava expresso que o Monarca era o chefe do Poder Executivo e o exercia por meio dos seus ministros. Entretanto, é possível afirmar - como já o fez Monteiro (1939) - que o Executivo consistia, de fato, apenas na figura do Imperador.

\footnotetext{
${ }^{31}$ No final de 1824, foi realizado o pleito para a escolha dos membros da Assembleia Geral, a eleição para a Câmara de Deputados e a definição das indicações das listas tríplices para o Senado. No entanto, o Monarca adiou por mais de um ano a convocação do primeiro parlamento. Os representantes do legislativo - após determinação do Imperador, instalaram-se apenas em 03 de maio de 1826. Tratava-se, também já atestado por Costa (2015), de desrespeito aos dispositivos constitucionais.

32 O art. 101 - parágrafo VI - da Constituição de 1824 permitia, ao titular do Poder Moderador, nomear e demitir ministros sem qualquer interferência do Legislativo.
} 
Nenhum poder do Estado é composto de membros demissíveis por vontade alheia, e os ministros, segundo a Constituição (...), eram nomeados e demitidos livremente pelo Imperador, que para esse fim não consultava o Conselho de Estado, como devia fazer quando quisesse exercer todas as outras atribuições do Poder Moderador. (...) Existência estava à mercê do Monarca, sujeito unicamente às inspirações da sua consciência, aos deveres da sua missão (MONTEIRO, 1939, p. 33-34).

Observados os fatos percebe-se que os ministros não apresentavam nenhum grau de independência. Por exemplo, o parágrafo VI do art. 101 da Constituição de 1824 permitia ao titular do Poder Moderador nomear e demitir ministros sem qualquer interferência do Legislativo, estando desobrigado inclusive de consultar o Conselho do Estado.

Contudo, na passagem da década de 1820 para a de 1830, o projeto centralista perdeu adesão. O Imperador e Defensor Perpétuo do Brasil havia perdido a autoridade que lhe era legitimada pela Carta Constitucional de 1824. Se inicialmente a Assembleia foi fechada, os Andradas exilados, revoltas provinciais aquietadas à força, o Imperador acabou por se distanciar gradativamente dos aliados que fizera até a sua abdicação em 07 de abril de 1831.

\section{O Supremo Tribunal Federal (STF) e a questão do Poder Moderador na atualidade}

A Constituição da República Federativa do Brasil de 1988 (art. 2º ) celebra a separação dos poderes Executivo, Legislativo e Judiciário. Intentando impedir que um dos Poderes usurpe as funções de outro, assegurou-se que são independentes e harmônicos entre si. Nesse panorama, a Lei Maior acabou por criar mecanismo de controles recíprocos ${ }^{33}$, ou seja, enquanto um poder controla os demais, é por eles controlado, reforçando a assertiva de Montesquieu de que somente o poder controla o poder: apenas a divisão e a harmonia entre os poderes é que podem garantir a organização do Estado Democrático de Direito (MONTESQUIEU, 1996 [1748]).

O Supremo Tribunal Federal (STF) - órgão máximo do Poder Judiciário - tem a função primordial de resguardar os dispositivos constitucionais; contudo, muitas vezes aquele órgão acaba intervindo no intuito de corrigir as falhas dos demais Poderes. Exemplo dessa interposição é a permissão do referido Tribunal de requerer ao Poder Legislativo a correção de regras falhas e editadas (ASSIS, 2012). Diante de suposta atuação equivocada do Poder Legislativo, o STF intenta corrigir os atos daquele poder para evitar a nulidade das suas ações (CRUZ, 2004).

É fundamental analisar se, no caso apontado acima, o STF estaria arrogando a si a atribuição do exercício de uma espécie peculiar de Poder Moderador. No âmbito do arranjo das

\footnotetext{
${ }^{33}$ É possível declarar que o Poder Executivo exerce o controle via sanção e veto, enquanto o Poder Legislativo, através das suas Comissões de Constituição e Justiça, possui o poder de rejeitar Medidas Provisórias. Já o Judiciário exerce - dentre outros tipos de controle - o controle concentrado: as decisões proferidas pelo Supremo Tribunal Federal validando (ou não) atos e leis têm efeito em todo o alinhamento jurídico.
} 
instituições políticas brasileiras, o Poder Moderador desapareceu após a queda do II Reinado (1840-1889). Entrementes, a sua retomada no período republicano foi reclamada em diferentes momentos históricos e das mais diversas formas. Exemplo dessa assertiva é a proposta de reforma política do advogado e político gaúcho Antônio Augusto Borges de Medeiros (1863-1961). O autor pensou - como opção republicana - a função do Poder Moderador centrado na figura do presidente. Borges de Medeiros - no livro O poder moderador na República Presidencial (1933) propôs o modelo de presidencialismo parlamentarizado ou de gabinete. No apêndice do seu livro, Borges de Medeiros apresentou o Anteprojeto de Constituição Federal para o Brasil, definindo no Artigo 82 a natureza do Poder Moderador no regime de governo republicano.

O Poder Moderador é delegado privativamente ao presidente da República. O presidente é o supremo magistrado da Nação, e o seu primeiro representante, a quem incumbe incessantemente velar sobre os destinos da República e sobre a conservação, equilíbrio e independência dos demais poderes políticos, assim como a inviolabilidade dos direitos fundamentais (MEDEIROS, 2002, p. 14041).

Se não é possível adotar o parlamentarismo, a república presidencialista necessitaria de profunda reforma na Constituição de 1891. Entre as propostas reformistas de Borges de Medeiros, destacavam-se: 1) O presidente da República, na função do Poder Moderador, será apenas Chefe de Estado; 2) A execução dos atos do poder executivo será delegada a um Conselho de Ministros, o qual, pelas decisões coletivas a serem tomadas, garantiriam política e juridicamente as liberdades públicas; 3) O presidente da República indica os ministros, porém estes apenas seriam nomeados com a chancela da maioria do voto parlamentar; 4) Em caso de vacância na presidência da República, ocupariam o cargo, respectivamente, o presidente do Conselho de Ministros, o presidente da Assembleia Nacional e o presidente do Supremo Tribunal Federal.

Borges de Medeiros defendia, em 1933, um modelo de governo presidencialista, no qual o presidente da República, eleito diretamente pelo voto popular, se constituiria em chefe de Estado, depositário de um poder moderador, a ser acionado sempre que surgissem impasses entre os poderes. A chefia do governo ficaria a cargo de um primeiro ministro, para administrar o País através de um gabinete de ministros, que teria ou perderia a confiança do Parlamento, dependendo do rumo das ações governamentais, a serem tomadas dentro de um contexto de co-responsabilidade entre o Executivo e o Congresso Nacional. Num impasse maior, poderia o presidente convocar novas eleições, para que ao povo se devolvesse a decisão sobre a maioria parlamentar, capaz de decidir sobre o tipo de governo e as ações conseqüentes reclamadas pela nação (FACCIONI, 2001, p. 17).

Borges de Medeiros foi influenciado pelo debate jurídico-político da sua época, o qual ocorreu durante a República de Weimar (1918-1933). Dentre os debatedores estavam os juristas Carl Schmitt (1888-1985), Hans Kelsen (1881-1973) e Hermann Heller (1891-1933): um dos 
temas fundamentais discutido por aqueles juristas era a reflexão acerca dos conceitos de Estado e Constituição $^{34}$. Inserido naquele contexto intelectual, Borges de Medeiros observava a necessidade da implantação do presidencialismo de gabinete, o qual separaria a chefia do Estado (Presidente) da chefia do governo (Conselho de Ministros). Portanto, nessa proposta, o presidente da República poderia exercer as suas prerrogativas constitucionais como Poder Moderador. O projeto de reformas de Borges de Medeiros apontava para a hipertrofia do poder executivo na então recente história republicana, principal causa da concentração de poder na figura do presidente.

A supremacia do Poder Executivo sobre o Legislativo, e a intervenção legal e extralegal do presidente nos negócios políticos dos Estados, acarretaram desequilíbrios no ritmo funcional das instituições, contribuindo para alimentar o espírito da indisciplina e de revolta, que, latente sempre, vinha se manifestando, com frequência em explosões esporádicas [...] Compete-lhe, portanto, as funções que constituem propriamente o governo, na sua acepção restrita. Exercendo o presidente o poder moderador, poder neutral, mediador, está visto que não mais deverá chefiar o Executivo, que é um dos poderes sujeitos à vigilância daquele. Se fora permitida a acumulação, estaria ipso facto violada a neutralidade do presidente e comprometida irremediavelmente a virtualidade e a ação do poder moderador. Não sendo isso possível, forçoso se torna que o Executivo seja delegado a uma entidade coletiva, denominada conselho de ministros, ou simplesmente ministério [...] O Executivo unipessoal implicaria o aparecimento de um governo ditatorial. (SOUZA PINTO, 2002, p. 58 e 69).

Nas discussões que antecederam a Constituição de 1934, houve a tentativa de conferir ao STF a função de Poder Moderador, a qual acabou malograda ${ }^{35}$. Porém, novamente, após o golpe de 1937, o retorno do Poder Moderador foi reclamado pelo Chefe do Poder Executivo, com aquele poder não se separando da função presidencial. No golpe de 1964, ficava implícito que as Forças Armadas poderiam assumir o papel de Poder Moderador ${ }^{36}$; e, hodiernamente, aquela função é reivindicada pelo STF. Assim, em todo o período republicano, em maior ou menor proporção, o tema do Poder Moderador vai adquirindo os mais diversos matizes (BASTOS, 2015).

\footnotetext{
${ }^{34}$ Sobre esse assunto, consultar: SCHMITT, Carl. O Conceito do Político / Teoria do Partisan. Belo Horizonte: Del Rey, 2008; SCHMITT, Carl. Teoría de La Constitución. Madrid: Alianza Universidad Textos, 2003; KELSEN, Hans. La garantia jurisdiccional de la Constitucion: la justicia constitucional (1928). In: Escritos sobre la democracia y el socialismo. Madrid: Editorial Debate, 1988; KELSEN, Hans. Teoría general del Estado (1925). Madrid: Editorial Labor, 1934; HELLER, Herman. Metas y límites de una reforma de la Constitución alemana. In: El sentido de la política y otros ensayos. Valencia: Pre-Textos, 1996 e HELLER, Herman. Las ideas políticas contemporáneas (1930). Granada: Editorial Comares, 2004.

${ }^{35}$ Uma proposta do constituinte João Mangabeira chegou a atribuir ao STF a prerrogativa de Poder Moderador e colocava a Suprema Corte como o grande poder político da Nação. A proposta, como se sabe, foi derrotada (BASTOS, 2015). Necessário recordar que também houve discussões travadas no âmbito da subcomissão do Itamaraty em 1933: uns defendiam a ideia de um Poder Coordenador (espécie de Quarto Poder) exercido por um Conselho Nacional, enquanto outros defendiam o restabelecimento do Conselho de Estado do Império (aduzido algumas vezes no Congresso durante a Primeira República). Fato é que tanto uma, quanto a outra proposta de Quarto Poder, acabaram sendo podadas e emasculadas pelos constituintes (SIMÕES, 1978).

${ }^{36}$ Importante rememorar que no decênio de 1930, os militares também reclamaram (informalmente e ilegalmente), para resolver as crises políticas, a função de Poder Moderador (PEREIRA, 2016).
} 
Dentre os juristas contemporâneos que interpretam que o Supremo Tribunal Federal assume o papel de Poder Moderador na República Federativa do Brasil, destaca-se o Ministro do STF, José Antonio Dias Toffoli. Em palestra intitulada O Poder Moderador no Brasil: os Militares e o Poder Judiciário (proferida no Instituto de Artes da Universidade Estadual Paulista em 04 abril de 2014), assim o citado Ministro referiu-se ao STF: "Hoje ele é o Poder Moderador".

Igualmente, o advogado constitucionalista Marcello Cerqueira propugna a atuação do Supremo Tribunal Federal como Poder Moderador: "O Poder Moderador incumbe ao Supremo Tribunal Federal" (CERQUEIRA, 2016). Isso sem mencionar o ex-presidente da Ordem dos Advogados do Brasil, Marcus Vinicius Coelho, que admite que o STF deva desempenhar papel moderador no desenho institucional delineado pela Carta Magna de 1988 (PEREIRA, 2016). Inclui-se, ainda, o Ministro Maurício Corrêa, que em 18 de setembro de 2003 (quando presidente do Supremo Tribunal Federal), em solenidade dos 175 anos do Supremo Tribunal de Justiça (antecessor do STF), mencionou a competência moderadora do STF - aliás, segundo Corrêa (2003), órgão "que dá a última palavra sobre a interpretação da Constituição brasileira". Na mesma cerimônia discursou Teori Albino Zavascki, Ministro do Superior Tribunal de Justiça (posteriormente Ministro do Supremo Tribunal Federal): “A Suprema Corte (...) representa poder moderador do Estado" (ZAVASCKI, 2003).

Apesar das várias conjecturas teóricas acerca do Poder Moderador no século XX e início do século XXI, a implantação prática daquele poder se apresenta incompatível com o disposto no art. $2^{\circ}$ da Constituição da República Federativa do Brasil de 1988. No entanto, atualmente, a jurisdição constitucional tem levado o STF a arbitrar sobre muitos atos do Legislativo ${ }^{37}$, seja validando e legitimando uma decisão dos órgãos representativos, ou invalidando os atos da Casa Legisladora (VIEIRA, 2008).

Em 05 de maio de 2016, o STF suspendeu o mandato do deputado carioca Eduardo Cosentino da Cunha, então Presidente da Câmara dos Deputados. Restou expressa, naquela

\footnotetext{
${ }^{37} \mathrm{Na}$ Constituição Imperial o Poder Judiciário não exerceu o controle de constitucionalidade. O Supremo Tribunal tinha competência limitada (poder subordinado). Ou seja, não se reconheceu aos magistrados o poder de recusar atos do Legislativo ou do Executivo; mesmo em atos do poder público que desviava de constitucionalidade, pois o Poder Moderador executava essa função. O Imperador exercendo o Poder Moderador podia vetar atos do parlamento e até mesmo dissolvê-lo. Também podia destituir Ministérios e conceder "graças" e indultos ao revogar decisões judiciais. A constitucionalidade dos atos dos outros poderes era controlada pelo Poder Moderador. Ou seja, mesmo a Carta Imperial não prevendo (expressando de maneira direta) tipos de controle de constitucionalidade das leis (como fizeram as Constituições Republicanas via Poder Judiciário), é possível afirmar que havia viabilidade constitucional; tal controle, mesmo que eminentemente político (baseado diretamente na Constituição), foi exercido pelo Poder Moderador. Expressou um jurista: "o Poder Moderador, além de inspecionar os demais poderes, tem atribuição de expressar, de sancionar as leis e, consequentemente, de vetá-las, exercendo, na prática, um controle de constitucionalidade" - controle eminentemente político e não jurídico. Inclusive, em muitas oportunidades, por questões políticas, o controle não foi exercido - mesmo quando existentes atos flagrantemente inconstitucionais. Exemplo: mesmo contrariando a Constituição de 25 de março de 1824, foi aprovado Código Criminal que trazia a pena do açoite (SAMPAIO JUNIOR, 2006, p. 262).
} 
ocasião, a violação das atribuições constitucionais do Congresso Nacional, uma vez que a Carta Magna confere exclusivamente ao Poder Legislativo a prerrogativa de cassar os mandatos parlamentares: "Só os eleitos podem dispor do mandato dos eleitos - eis o princípio democrático que a Corte Suprema decidiu ignorar" (MAGNOLI, 2016, p. A10). Nesse caso, quando o STF suspendeu o mandato do mencionado presidente da Câmara dos Deputados, colocou-se acima das fronteiras legais ${ }^{38}$ e da regra da separação de poderes.

No dia 05 de dezembro de 2016 também foi presenciado o inusitado ato do Ministro do STF (Marco Aurélio Mello), o qual tentou afastar o parlamentar alagoano, José Renan Vasconcelos Calheiros, da Presidência do Senado. Aquela tentativa acabou derrubada três dias depois, quando o plenário do STF decidiu que o aludido senador não precisaria ser afastado do cargo, ainda que tenha se tornado réu sob a acusação de desvio das verbas de gabinete para custear pensão alimentícia da filha. No entanto, ficou estabelecido que o senador, na condição de réu, não poderia ocupar o cargo da Presidência da República, mesmo estando na linha sucessória. Nessa ocorrência específica, houve, por parte do STF, tentativa de violação das prerrogativas do Congresso? ${ }^{39}$

O STF, pelos artigos constantes na Constituição Federal, apenas deve ponderar sobre as prerrogativas inerentes ao controle de constitucionalidade das leis. Constitucionalmente, o STF não possui a função de interferir em outros temas da Administração Pública, como nos julgamentos de improbidade administrativa envolvendo membros do Executivo. Ao questionar as ações administrativas do Poder Executivo - arrogando a si poder fiscalizador e corretor -, o STF atuaria como uma espécie de Poder Moderador, colocando-se acima dos demais poderes para o arbítrio dos conflitos.

Ao estabelecer condutas com o objetivo de corrigir "atos defeituosos" dos poderes Executivo e Legislativo, o STF estaria assumindo a prerrogativa de Poder Moderador, a qual se situa apenas no nível do discurso fictício, pois o STF - assim como qualquer outro poder republicano - não se situa acima das disputas entre as facções ideológicas e partidárias, e, portanto, não pode ser Poder Neutro. Nesses termos, transformar o STF - corpo técnico-jurídico em Poder Moderador extrapola o disposto na atual Constituição do Brasil e transgride a norma constitucional da separação de poderes: o STF é um órgão do Poder Judiciário que é guardião da Carta Magna, supremo defensor e intérprete da Constituição, e não proprietário dela.

\footnotetext{
${ }^{38}$ Este texto não pretende apurar se Eduardo Consentino da Cunha usou (ou não) o cargo de Presidente da Câmara dos Deputados para prejudicar as investigações da operação Lava Jato (investigação sobre corrupção envolvendo políticos e empreiteiras). É que essa foi a alegação do STF para afastar o parlamentar do Congresso. O objetivo neste ponto do trabalho é esclarecer se está (ou não) havendo invasão de competências no âmbito dos poderes estabelecidos na Constituição.

${ }^{39}$ Não é objetivo promover a defesa dos atos de José Renan Vasconcelos Calheiros, mas atentar para a reflexão, uma vez que a separação de Poderes inspirada na teoria de Montesquieu recusa a invasão de competências entre os poderes.
} 
As funções dos poderes Legislativo e Executivo são diversas das atribuições do Poder Judiciário. Diante disso, não se pode admitir que o STF se transforme em Poder Legislativo ou Poder Executivo. Ao intervir como Poder Moderador, o STF impõe condutas aos demais Poderes, violando de forma arbitrária os dispositivos constitucionais que o próprio órgão deveria defender. Contudo, não se trata de reduzir o Poder Judiciário a mero cumpridor da letra fria da lei; mas surge o risco do ativismo judiciário - e a consequente judicialização da política - neutralizar as conquistas que se deram pela via democrática, ao mesmo tempo em que contraria a competência que a Carta Constitucional atribuiu ao STF (SANTOS, 2009).

Adequado reforçar que não se trata da defesa de um STF serviçal do Poder Executivo ou do Poder Legislativo, uma vez que a subordinação prejudica a sua função primordial de guardião da Carta Magna. Antes, cabe ao STF defender a Constituição, a qual não é passível de ser apropriada por nenhum dos três poderes republicanos. Assim, o STF pode e deve tomar iniciativas em benefício dos cidadãos brasileiros; no entanto, o Tribunal Maior não detém a prerrogativa constitucional de Poder Moderador, pois se a retivesse abriria as portas para a arbitrariedade do Poder Judiciário.

Do ponto de vista de Benjamin Constant, o Poder Moderador apenas arbitraria os conflitos existentes; e apenas nesses momentos o poder atribuído à Coroa estaria acima dos demais poderes. D. Pedro I, por seu turno, concentrou o Poder Moderador e, embora o exercitando por meio dos seus Ministros, o Poder Executivo. Ou seja, objetivou a concentração do poder pessoal do Imperador. Devemos lembrar que os art. 98 e 102 da Constituição de 1824 não colocava o Monarca acima da Carta Constitucional. Pelo contrário, exigia do Imperador - no exercício do Poder Moderador - promover a vigilância da independência, equilíbrio e harmonia dos três poderes, preservando, desse modo, a ordem constitucional. Assim, na atual República Federativa do Brasil, o STF não pode arbitrar permanentemente sobre as prerrogativas constitucionais que são próprias do Poder Legislativo ou do Poder Executivo; haja vista que a Carta Constitucional de 1988, quando celebrou a separação dos Poderes, não instituiu o Poder Moderador.

\section{Considerações finais}

O artigo apresentou alguns elementos teóricos para se refletir sobre a necessidade da definição dos limites da legalidade constitucional. D. Pedro I, ao exercer o Poder Moderador, não poderia estar acima da Carta Magna, fator primordial que diferencia a Monarquia Constitucional da Monarquia arbitrária embasada no fortalecimento do poder pessoal do Imperador. Da mesma maneira, o STF, na condição de guardião da Constituição Federal, não pode reescrever a Carta Magna arbitrariamente, pois o Estado Democrático ruiria ante as ações discricionárias de 
qualquer dos três poderes, em nosso caso, do Poder Judiciário: os limites e modos que os poderes políticos estão estabelecidos - suas atribuições e independência - devem estar sujeitos à lei. A pátria não pode estar sujeita à vontade ilimitada, mas ao cumprimento estrito das normas constitucionais.

Na prática, o Poder Executivo e o Poder Moderador, no I Reinado, se sobrepunham aos demais poderes. O Poder Moderador abarcava funções do Poder Executivo e ambos estavam concentrados nas mãos de D. Pedro I. Por outro lado, é possível afirmar que no desenho institucional traçado pela Carta Constitucional de 1988, compete ao STF somente intervir quando ameaçada a Lei Maior. Por conseguinte, o STF não pode exercer o papel de Poder Moderador, uma vez que na conjuntura atual inexiste instituição que possa ser comparada ao Imperador no sentido de se situar acima dos interesses das facções ideológicas e partidárias, como propõe a teoria política de Benjamin Constant.

$\mathrm{Na}$ contemporaneidade, qualquer dos três poderes que reivindique a função de controle dos demais poderes diverge da teoria tripartite expressa na Constituição vigente. Na atual conjuntura política, qualquer intenção ou proposta que vise institucionalizar o Poder Moderador, estaria reivindicando a constituição de um poder que não está previsto na nossa última Carta Magna; desviando-se, portanto, dos pilares constitucionais.

A condição de guardião da Constituição Federal não oferece ao STF competência para tratar de questões reservadas à esfera política. Se a inexistência do Poder Moderador foi compensada de alguma maneira pela função desempenhada pelo STF de guardião da Carta Constitucional, talvez seja crucial não confundirmos o conceito de Poder Moderador com o conceito de fiscalizador dos preceitos constitucionais. Enfim, parece que enquanto no Primeiro Reinado (1822-1831) o Poder Moderador existiu de fato na Carta Constitucional, nas instituições políticas contemporâneas o Poder Moderador é apenas imaginário, bastando observar as leis dispostas na Constituição atual. A chave de toda a organização institucional e política passa pela divisão das funções e atribuições dos poderes. Cabe ao STF o uso prudente e adequado das suas prerrogativas, contribuindo para estruturação de um sistema político estável, duradouro e democrático. 


\section{Referências}

AMBROSINI, Diego Rafael. Do Poder Moderador: uma análise da organização do poder na construção do Estado imperial brasileiro. Dissertação (Mestrado em Ciência Política). São Paulo, Universidade de São Paulo (USP), 2004.

ASSIS, Christiane Costa. O Supremo Tribunal Federal Como Poder Moderador: uma Análise Discursiva. Revista Direito Público (DPU), Brasília, 47, p. 60-70, set./out., 2012.

BARROSO, Luís Roberto. Judicialização, ativismo judicial e legitimidade democrática. Revista [Syn]Thesis, Rio de Janeiro, vol.5, nº 1, p.23-32, 2012.

BASTOS, Aurélio Wander. Notas sobre a Evolução Política e Institucional da Revolução Francesa/Introdução. In: CONSTANT, Benjamin. Princípios políticos constitucionais: princípios políticos aplicáveis a todos os governos representativos e particularmente à Constituição atual da França (1814). Rio de Janeiro: Freitas Bastos Editora, 2014 [1815].

BASTOS, Erico Araújo. STF e poder moderador: política à margem do poder constituinte na atuação do Supremo Tribunal Federal. Curitiba: Juruá, 2015.

BRASIL. A Constituição Brasileira de 1824. In: NOGUEIRA, Octaciano. 1824. 3. ed. Brasília: Senado Federal. (Subsecretaria de Edições Técnicas), p.63-88, 2012.

Constituição da República Federativa do Brasil, de 5 de outubro de 1988. 35. ed. Brasília: Câmara dos Deputados, Edições Câmara, 2012.

Assembleia Constituinte. Annaes do Parlamento Brazileiro 1823 (Pronunciamento proferido por Dom Pedro I na Assembleia Constituinte, na Sessão Imperial da Abertura (Fala do Trono), em 3 de maio de 1823). Rio de Janeiro: Typographia do Imperial Instituto Artistico, 1874.

Assembleia Legislativa. Anais da Câmara dos Deputados [Pronunciamento proferido por Dom Pedro I na Câmara dos Deputados, na Sessão Imperial da Abertura (Fala do Trono), em 3 de maio de 1829]. Rio de Janeiro: Typographia de H. J. Pinto, 1877.

Câmara dos Deputados. Organisações e Programmas Ministeriaes (1822 a 1889). Organização: Secretaria da Câmara dos Deputados. Rio de Janeiro: Câmara dos Deputados, (Imprensa Nacional), 1889.

Câmara dos Deputados. 1889 Sessão Ordinária. Organização: Secretaria da Câmara dos Deputados. Rio de Janeiro: Câmara dos Deputados, (Imprensa Nacional), 1889.

CASTRO, Chico. A noite das garrafadas. Brasília: Edições do Senado Federal - vol. 173, 2012.

CERQUEIRA, Marcello. O Protocolo Vargas. O Globo, Rio de Janeiro, 14 de abril, 2016.

CONSTANT, Benjamin. Princípios de política aplicáveis a todos os governos. Rio de Janeiro: Topbooks, 2007 [1810].

Princípios políticos constitucionais: princípios políticos aplicáveis a todos os governos representativos e particularmente à Constituição atual da França (1814). Rio de Janeiro: Freitas Bastos Editora, p. 03-13, 2014 [1815]. 
Reflexões sobre as Constituições e as garantias. In: . Escritos de Política. São Paulo: Martins Fontes, 2005 [1814].

CORRÊA, Maurício. Discurso dado na solenidade comemorativa dos 175 anos da Corte - STF. Fala proferida na "celebração do aniversário de 175 anos da Lei de 18 de setembro de 1828, que criou o Supremo Tribunal de Justiça (antecessor do STF)" - realizado no Salão Branco do Supremo Tribunal Federal (Brasília), 18 de set. de 2003.

COSTA, Emília Viotti da. Brasil: história, textos e contextos. São Paulo: Editora Unesp, 2015.

COSTA JUNIOR, Luiz Roberto Guimarães da. Poder moderador: o quarto poder no Segundo Reinado (1840-1889). Dissertação (Mestrado em Ciência Política). Campinas, Universidade Estadual de Campinas (UNICAMP), 2002.

COSTA, Pedro Pereira da Silva. D. Pedro I. São Paulo: Editora Três, 1974.

CRUZ, Álvaro Ricardo de Souza. Jurisdição constitucional democrática. Belo Horizonte: Del Rey, 2004.

FACCIONI, Victor José. Prefácio. In: MEDEIROS, Borges de. O poder moderador na república presidencial. São Paulo: EDUCS, 2002.

FAUSTO, Bóris. História Concisa do Brasil. 2 ed. São Paulo: Edusp, 2006.

GILENO, Carlos Henrique. A Carta Constitucional de 1824 e a organização da estrutura de poder institucional no Brasil. Universidade Federal Fluminense: Revista Escrita da História, v. 3, p. 5080, 2016.

HELLER, Herman. Metas y límites de una reforma de la Constitución alemana. In: El sentido de la política y otros ensayos. Valencia: Pre-Textos, 1996.

Las ideas políticas contemporáneas (1930). Granada: Editorial Comares, 2004.

HOLANDA, Sérgio Buarque de. O Poder Pessoal. In: à República. 4. Ed. São Paulo: Editora DIFEL, 1985, p. 59-78. . O Brasil Monárquico: do Império

KELSEN, Hans. La garantia jurisdiccional de la Constitucion: la justicia constitucional (1928). In: Escritos sobre la democracia y el socialismo. Madrid: Editorial Debate, 1988.

. Teoría general del Estado (1925). Madrid: Editorial Labor, 1934

LANZONI, Augusto. Iniciação às Ideologias Políticas. 4. Ed. São Paulo: Editora Ícone, 1995.

LEAL, Aurelino. História Constitucional do Brasil. Brasília: Edições do Senado Federal, 2014.

LYNCH, Christian Edward Cyril. Da organização dos políticos: a Monarquia Constitucional e o Poder Moderador. In: __ Monarquia sem despotismo e liberdade sem anarquia: o pensamento político do Marquês de Caravelas (1821-1836). Belo Horizonte: Editora UFMG, 2014.

O discurso político monarquiano e a recepção do conceito de poder moderador no Brasil (1822-1824). Dados (Revista de Ciências Sociais); 48 (3), jul. set., p. 611-653, 2005. 
Os órfãos de Montesquieu: o constitucionalismo esquecido dos monarquianos franceses (1789). In: Revista Estudos Políticos, Rio de Janeiro, n. 2 (2011/01), jun., p. 81-102, 2011.

LUSTOSA, Isabel. D. Pedro I: um herói sem nenhum caráter. São Paulo: Companhia das Letras, 2006.

LYRA, Maria de Lourdes Viana. O Império em Construção: Primeiro Reinado e Regência. São Paulo: Atual, 2000.

MACAULAY, Neill. Dom Pedro I: a luta pela liberdade no Brasil e em Portugal, 1798-1834. Rio de Janeiro: Record, 1993.

MAGNOLI, Demétrio. Sob a égide do Poder Moderador. Folha de São Paulo, São Paulo, 07 de maio. Poder, p. A10, 2016.

MEDEIROS, Borges de. O poder moderador da república presidencial. São Paulo: EDUCS, 2002.

MERCADANTE, Paulo. O Poder Moderador. In: - A consciência conservadora no Brasil: contribuição ao estudo da formação brasileira. 2. ed. Rio de Janeiro: Editora Civilização Brasileira, 1972.

MONTEIRO, Tobias. História do Império: o Primeiro Reinado. Tomo I. Rio de Janeiro: F. Briguiet \& Cia - Editores, 1939.

MONTESQUIEU, Charles de Secondat. O espírito das leis. 5 ed. São Paulo: Martins Fontes, 1996 [1748].

NOGUEIRA, Octaciano. 1824. 3. ed. Brasília: Senado Federal. (Subsecretaria de Edições Técnicas), p.9-54, 2012.

OLIVEIRA, Cecilia Helena de Salles. A Independência e a construção do Império (1750-1824). São Paulo: Atual, 1995.

PEREIRA, Merval. Democracia e Poder Moderador. O Globo, Rio de Janeiro, O País, 5 de junho, p. 14, 2016.

QUIRINO, Célia N. Galvão. Introdução e Notas. In: CONSTANT, Benjamin. Escritos de Política. São Paulo: Martins Fontes, 2005 [1815].

SAMPAIO JUNIOR, José Herval. O Poder Moderador como origem do controle de constitucionalidade no Brasil. Revista Direito e Liberdade, Mossóro, v.4, n.3, p. 229-266, jul./dez. 2006.

SANTOS, Boaventura de Souza. A contrarrevolução jurídica. Folha de São Paulo, 04 de dezembro. Opinião, p. A3, 2009.

SCHMITT, Carl. O Conceito do Político / Teoria do Partisan. Belo Horizonte: Del Rey, 2008. . Teoría de La Constitución. Madrid: Alianza Universidad Textos, 2003. 
SIMÕES, Teotonio. Repensando Alberto Torres: O Pensamento Político de Alberto Torres. Dissertação (Mestrado em Ciência Política). São Paulo, Pontifícia Universidade Católica de São Paulo (USP), 1978.

SOUZA PINTO, Paulo Brossard de. Prefácio da 2. ed. In: MEDEIROS, Borges de. O poder moderador da república presidencial. São Paulo: EDUCS, 2002.

TOFFOLI, José Antonio Dias. O Poder Moderador no Brasil: os Militares e o Poder Judiciário. Palestra proferida na "Conferência: 50 anos de Golpe Militar: memória, história e Direitos Humanos" realizada pela Universidade Estadual Paulista - UNESP (São Paulo), 04 de abr. de 2014.

TORRES, João Camilo de Oliveira. História do Império. Rio de Janeiro: Record, 1963.

Interpretação da Realidade Brasileira. 2 ed. Rio de Janeiro: Editora José Olympio, 1973.

VASCONCELOS, Zacarias de Góis e. Da natureza e dos limites do poder moderador. In: OLIVEIRA, Cecilia Helena de Salles (Org.). Zacarias de Góis e Vasconcelos. São Paulo: Editora 34, 2002.

VIEIRA, José Ribas. Epílogo. In: CONSTANT, Benjamin. Princípios políticos constitucionais: princípios políticos aplicáveis a todos os governos representativos e particularmente à Constituição atual da França (1814). Rio de Janeiro: Freitas Bastos Editora, 2014 [1815].

VIEIRA, Oscar Vilhena. Supremocracia. Revista Direito GV, São Paulo, 4(2), p. 441-464, jul./dez. 2008.

ZAVASCKI, Teori Albino. Discurso dado na solenidade comemorativa dos 175 anos da Corte STF. Fala proferida na "Celebração do aniversário de 175 anos da Lei de 18 de setembro de 1828, que criou o Supremo Tribunal de Justiça (antecessor do STF)" - realizado no Salão Branco do Supremo Tribunal Federal (Brasília), 18 de set. de 2003.

Recebido em: 18-03-2017;

Revisado em: 09-05-2017;

Publicado em 04-05-2018. 